\title{
Recent books
}

The following is a selection of recent publications in the field of conservation of existing structures and the history of building and civil engineering. It is not comprehensive. Readers are invited to notify the Editor about relevant new books for inclusion in a similar review in early 2018. Subject to availability of space, some of these books will be reviewed in Engineering History and Heritage.

Addis W (ed.) (2016) Structural and Civil Engineering Design. Routledge, Abingdon-on-Thames, UK.

Aita D, Pedemonte O and Williams K (eds) (2015) Masonry Structures: Between Mechanics and Architecture. Birkhäuser, Basel, Switzerland. Andrews D, Bedford J and Bryan P (2015) Metric Survey Specifications for Cultural Heritage, 3rd edn. Historic England, London, UK. Atkinson FGB (2015) History of the North London Railway. Volume 1: London's North Western Electrics. The North London Railway Historical Society, London, UK.

Badura S (2015) Das Pretziener Wehr an der Elbe. Band 17 der Schriftenreihe Historische Wahrzeichen der Ingenieurbaukunst in Deutschland. Bundesingenieurkammer, Berlin, Germany (in German)

Baridon L, Garric J-P and Richaud G (eds) (2016) Les Leçons de la Terre: François Cointeraux (1740-1830), Professeur d'Architecture Rurale. Institut National d'Histoire de l'Art/Editions des Cendres, Paris, France (in French).

Barton B (2016) Civil Engineering Heritage: East Midlands. Ruddocks Publishing Ltd, Lincoln, UK

Barton N and Myers S (2016) The Lost Rivers of London, 3rd edn. Historical Publications, Whitstable, UK.

Becchi A, Carvais R and Sakarovitch J (eds) (2015) L'Histoire de la Construction: Un Méridien Européen. Association Francophone d'Histoire de la Construction, Paris, France (in French).

Beckh M (2015) Hyperbolic Structures. Shukhov's Lattice Towers Forerunners of Modern Lightweight Construction. Wiley, Chichester, UK.

Berthonnet A (2015) L'Entreprise Familiale Joyeux: Six Générations d'Entrepreneurs, 1858 à nos Jours. InSiglo, Rueil-Malmaison, France (in French).

Bologna A and Gargiani R (2016) The Rhetoric of Pier Luigi Nervi: Forms in Reinforced Concrete and Ferro-Cement. EPFL Press, Lausanne, France.

Bond S and Worthing D (2016) Managing Built Heritage: the Role of Cultural Values and Significance, 2nd edn. Wiley-Blackwell, Chichester, UK.

Bühler D (2015) Museum aus Gegossenem Stein: Betonbaugeschichte im Deutschen Museum. Deutsches Museum, Munich, Germany (in German).

Burton A (2015) Thomas Telford: Master Builder of Roads and Canals. Pen \& Sword Books, Barnsley, UK.

Campbell JWP, Bill N, Driver M et al. (eds) Further Studies in the History of Construction: Proceedings of the Third Annual Conference of the Construction History Society. Construction History Society, Cambridge, UK.

Capecchi D and Ruta G (2015) Strength of Materials and Theory of Elasticity in 19th Century Italy. A Brief Account of the History of Mechanics of Solids and Structures. Springer, Berlin, Germany.

Cassis Y (2016) Infrastructure Finance in Europe: Insights into the History of Water, Transport, and Telecommunications. University Press, Oxford, UK.

Castrucci C (2016) Le Quartier du Port de Marseille 1500-1790. Une Réalité Urbaine Restituée. Université de Provence, Provence, France (in French).

Christianson J and Marston CH (eds) (2015) Covered Bridges and the Birth of American Engineering. Historic American Engineering Record, Washington, DC, USA.

Christopher J (2015) Brunel's Kingdom: in the Footsteps of Britain's Greatest Engineer. The History Press, Stroud, UK.

Clarke M (2016) The Leeds \& Liverpool Canal - a History, 2nd edn. Milepost Research, Lancashire, UK.
Claustre J and Margairaz D (eds) (2015) Mesurer et Construire Paris (Histoire Urbaine, No. 43). Société Française d'Histoire Urbaine, Paris, France (in French).

Cluzel J-S and Masatsugu N (eds) (2015) Le Sanctuaire d'Ise: Récit de la $62 e$ Reconstruction. Mardaga, Brussels, Belgium (in French).

Costanza B (2016) Building a Crossing Tower: A Design for Rouen Cathedral of 1516. Holberton, London, UK.

Courtenay L (ed.) (2016) The Engineering of Medieval Cathedrals (Studies in the History of Civil Engineering). Routledge, Abingdonon-Thames, UK.

Cross-Rudkin P (2016) Early Main Line Railways: Papers from the First International Early Main Line Railways Conference Held at Caernarfon in June 2014. Six Martlets Publishing, Suffolk, UK.

Davies W (2016) The Story of 'The Irish Mail': A London Train to Ireland Via Holyhead. Gwasg Carreg Gwalch, Llanrwst, Wales.

Delemontey Y and Graf F (2016) La Sauvegarde des Grandes Euvres de l'Ingénierie du XXe Siècle. Presses Polytechniques et Universitaires Romandes (Cahiers du TSAM), Lausannes, France (in French). Delemontey Y (2015) Reconstruire la France: l'Aventure du Béton Assemblé, 1940-1955. Éditions de la Villette, Paris, France (in French).

Devos R and Ortenberg A (2015) Architecture of Great Expositions 1937-1959: Messages of Peace, Images of War. Routledge, Abingdonon-Thames, UK.

Dow A (2015) The Railway: British Track Since 1804. Pen \& Sword Books, Barnsley, UK.

Durbin L (2015) Architectural Tiles: Conservation and Restoration, 2nd edn. Routledge, Abingdon-on-Thames, UK.

ECCS (The European Convention for Constructional Steelwork) (2015) The European Convention for Constructional Steelwork - History and Achievements 1955-2015. ECCS Publication 137. ECCS, Brussels, Belgium.

Etxepare L and García F (2016) Luis Vallet de Montano (1894-1982). Arquitecto de Frontera. Colegio Oficial de Arquitectos VascoNavarro, San Sebastián, Spain.

EURAC Research, Passive House Institute, Troi A and Bastian Z (eds) (2015) Energy Efficiency Solutions for Historic Buildings: A Handbook. Birkhauser, Basel, Switzerland.

Fife M (2015) British Airship Bases of the Twentieth Century. Fonthill Media Limited, Stroud, UK.

Francis R (2015) Penang Hill Funicular Railway: Remembering an Engineering Feat 1923-2010. Areca Books, Penang, Malaysia.

French G (2016) The History of Scott Wilson Kirkpatrick: From Individual Engineering Consultancy in 1924 to Major International Firm in 2010. Scott Wilson Kirkpatrick, London, UK.

Fuller L (ed.) (2016) Great Expectations: Buildings at Risk 2016-17. Save Britain's Heritage, London, UK.

Fwa TF (2016) 50 Years of Transportation in Singapore: Achievements and Challenges. World Scientific Publishing, Singapore.

Gargiani R (2013) Concrete from Archaeology to Invention 1700-1769. The Renaissance of Pozzolana and Roman Construction Techniques. EPFL Press, Lausanne, France and Routledge, Abingdon-on-Thames, UK.

Genestier P and Gras P (eds) (2015) Sacré Béton! Fabrique et Légende d'un Matériau du Future. Libel, Lyon, France (in French).

Gerhold D (2016) London Plotted: Plans of London Buildings c.14501720. London Topographical Society, Catarham, UK

Giles C and Williams M (eds) (2015) Ditherington Mill and the Industrial Revolution. Historic England, Swindon, UK.

Gonzalez P, Carlos J, Mártin R et al. (2015) Taller de Construcción Gótica: Workshop on Building Gothic Methods. Munilla-Leria, Madrid, Spain. Gould J and Gould C (2015) Coventry: The Making of a Modern City 1939-1973. Historic England, Swindon, UK. 
Graf F and Albani F (eds) (2015) Angelo Mangiarotti. La Tettonica dell'assemblaggio/The Tectonics of Assembly. Mendrisio Academy Press/Silvana Editoriale, Madrid, Spain.

Grantham MG (2016) Concrete Solutions: Proceedings of the 6th International Conference on Concrete Repair Held in Thessaloniki, Greece on the 20-23 June 2016. CRC Press, Taylor \& Francis Group, Boca Raton, FL, USA.

Hänsel J, Haspel J, Salge C and Wittmann-Englert K (eds) (2016) Baumeister - Ingenieure - Gartenarchitekten. Duncker \& Humblot, Berlin, Germany (in German).

Harper D (2015) River, Railway and Ravine: Foot Suspension Bridges for Empire. The History Press, Stroud, UK.

Harrison D (2015) The Thames Iron Works 1837-1912: A Major Shipbuilder on the Thames. Museum of London Archaeology, London, UK.

Hassler U (ed.) (2015) Der Lehrbuchdiskurs über das Bauen. Institut für Denkmalpflege und Bauforschung, Zürich, Switzerland (in German).

Heine E-C (ed.) (2016) Under Construction. Building the Material and the Imagined World. LIT Verlag, Berlin, Germany.

Hernu-Bélaud J (2015) De la Planche à la Page. Pierre Bullet et l'Architecture en France sous Louis XIV. Université Paris-Sorbonne, Paris, France.

Heyman J (2016) Geometry and Mechanics of Historic Structures. Instituto Juan de Herrera, Madrid, Spain.

Hillnhütter S (ed.) (2015) Planbilder: Medien der Architekturgestaltung. De Gruyter, Berlin, Germany.

Historic England (2016) Advice and Guidance: New Titles and Backlist. Historic England, Swindon, UK.

Historic England (2016) Engines of Prosperity: New Uses for Old Mills. Historic England, Swindon, UK.

Historic England (2016) Sourcing Stone for Historic Building Repair Historic England, Swindon, UK.

Historic England (2016) Understanding Historic Buildings: A Guide to Good Recording Practice. Historic England, Swindon, UK.

Historic England (2015) Practical Building Conservation Series (10 vols): Building Environment, Concrete, Conservation Basics, Earth, Brick and Terracotta, Glass and Glazing, Metals, Mortars, Renders and Plasters, Roofing, Stone, Timber. Ashgate Publishing Limited, Farnham, UK

Holzer SM (2015) Die Sauschwänzlebahn im Südschwarzwald. Band 16 der Schriftenreihe Historische Wahrzeichen der Ingenieurbaukunst in Deutschland. Bundesingenieurkammer, Berlin, Germany.

Holzer SM (2015) Statische Beurteilung historischer Tragwerke. Band 2, Holzkonstruktionen. Ernst und Sohn, Berlin, Germany.

Actes Sud, Ecole Nationale Supérieure d'Architecture Paris Malaquais (eds) (2016) Hommage à Joël Sakarovitch. Transmettre, Comprendre, Défricher. Ecole Nationale Supérieure d'Architecture, Paris, France.

Ibarra-Sevilla B (2015) Mixtec Stonecutting Artistry/El Arte de la Cantería Mixteca. Universidad Nacional Autónoma de Mexico, Mexico City, Mexico.

Iori T and Poretti S (eds) (2015) SIXXI: Storia dell'ingegneria Strutturale in Italia. Gangemi Editore, Rome, Italy, vol. 1-3 (in Italian).

Irwin L (2015) Messrs Lucas Brothers: the Great Victorian Contractors. Design + Digital Print for Loti Irwin, Chichester, UK.

Jarvis A (ed.) (2016) Port and Harbour Engineering: 6 (Studies in the History of Civil Engineering). Routledge, Abindon-on-Thames, UK.

Koch J (2015) L'Art de Bâtir dans les Châteaux Forts en Alsace: Xe-XIIIe Siècle. PUN, Éditions Universitaires de Lorraine, Nancy, France (in French).

Krieg SW and Pommer D (2015) Max Pommer: Architekt und Betonpionier. Sax-Verlag, Markleeberg, Germany (in German).

Kurrer K (2016) Eugen Geschichte der Baustatik. Auf der Suche nach dem Gleichgewicht, 2nd edn. Ernst \& Sohn, Berlin, Germany (in German).

Musée du Plâtre (2016) La Lettre Blanche No. 54, Mars 2016. Musée du Plâtre, Cormeilles-en-Parisis, France (in French).

Lalvani K (2016) The Making of India: the Untold Story of British Enterprise. Bloomsbury, London, UK.
Lemoine B (2016) The Eiffel Tower: the Three-Hundred-Metre Tower. Taschen, Cologne, Germany.

Maggs C (2016) Isambard Kingdom Brunel: the Life of an Engineering Genius. Amberley Publishing, Stroud, UK.

Mann A (2016) Historical Development of Structural Form. Essential Knowledge Series, EKT3. Institution of Structural Engineers, London, UK.

Mann A (2016) Historical Development of Structural Theories and Methods of Analysis - Context of Modern Computer Analysis. Essential Knowledge Series, EKT4. Institution of Structural Engineers, London, UK.

Marconi N (2015) Castelli e Ponti. Apparati per il Restauro nell'Opera di Mastro Nicola Zabaglia per la Fabbrica di San Pietro in Vaticano. Il Formichiere, Foligno, Italy (in Italian).

Mclvor L (2015) Canals: the Making of a Nation - a Journey into the Heart of Industrial Britain. BBC Books, London, UK.

Meissner I and Möller E (2015) Frei Otto. A Life of Research Construction and Inspiration. Edition Detail, Munich, Germany.

Menn C (2015) Brücken - Bridges. Scheidegger \& Spiess, Zurich, Switzerland.

Mills DR (2015) Effluence and Influence: Public Health, Sewers and Politics in Lincoln 1848-50. Society for Lincolnshire History and Archaeology, Lincoln, UK.

Minnis J and Morrison KA (2016) Buildings and Infrastructure for the Motor Car. Historic England, Swindon, UK.

Minnis J (2015) Curzon Street Station, Birmingham (Research Report). Historic England, Swindon, UK.

Minnis J (2016) The Railway Goods Shed and Warehouse in England. Historic England, Swindon, UK.

Mitchell M (2015) The Montrose \& Bervie Railway: a Study of Transport in South-East Kincardineshire 1770-1966. Lightmoor Press, Lydney, Gloucestershire.

Montel N (2015) Écrire et Publier des Savoirs au XIXe Siècle: une Revue en Construction, les 'Annales des Ponts et Chaussées', 1831-1866. Presses Universitaires de Rennes, Collection Carnot, Rennes, France (in French).

Newby F (ed.) (2016) Early Reinforced Concrete (Studies in the History of Civil Engineering). Routledge, Abingdon-on-Thames, UK.

O'Keeffe P and Simington T (2016) Irish Stone Bridges: History and Heritage, 2nd edn. Irish Academic Press, County Kildare, Ireland.

Owens V (2015) James Brindley and the Duke of Bridgewater Canal Visionaries. Amberley Publishing, Stroud, UK.

Palmer M and West I (2016) Technology in the Country House. Historic England, Swindon, UK.

Paye P (2015) The Axminster \& Lyme Regis Light Railway. The Oakwood Press, Usk, Wales.

Peixoto V (2016) 1st International Symposium on Building Pathology: Selected Papers Presented at the Symposium Held at the University of Porto, Portugal on the 24-27 March 2015. Emerald Group Publishing Limited, Bingley, UK.

Prince's Regeneration Trust (2015) The Green Guide for Historic Buildings, 2nd edn. The Stationary Office, London, UK.

Raynaud D (ed.) (2015) Géométrie Pratique Géomètres, Ingénieurs et Architectes XVIe-XVIIIe Siècles. Presses Universitaires de FrancheComté, Besançon, France (in French).

Richards J (2016) Buildings, Bridges and Tunnels: an Accidental History of Inventions ('It'll Never Work'). Franklin Watts, London, UK and Sydney, Australia.

Riehle T (2015) Rhine Bridges. Edition Axel Menges, Stuttgart, Germany and London, UK

Rinke M (2016) Vom Konstrukt zum Typus: der Wandel der strukturellen Form von Tragwerken im 18. Und 19. Jahrhundert. Deutscher Kunstverlag, Berlin, Germany (in German).

Roos J (2015) Rail Fastenings: the History of Major Component of Railway Track. Railfix Publications, Sittard, The Netherlands. 
Roth R (2015) From Rail to Road and Back Again? A Century of Transport Competition and Interdependency. Ashgate, Farnham, UK. Schädlich C (2015) Das Eisen in der Architektur des 19. Jahrhunderts. Geymüller, Aachen, Germany (in German).

Scheiffele W (2015) Das Leichte Haus - Utopie und Realität der Membranarchitektur. Edition Bauhaus 44, Spector Books, Leipzig, Germany (in German).

Schexnayder C (2015) Builders of the Hoosac Tunnel. Peter E. Randall, Portsmouth, NH, USA.

Schneider I (2016) Archimedes: Ingenieur, Naturwissenschaftler, Mathematiker, 2nd edn. Springer, Berlin, Germany (in German).

Stanbrook E (2016) Bishop Rock Lighthouse. Twelveheads Press, Truro, UK.

Stanbrook E (2016) Longships Lighthouse. Twelveheads Press, Truro, UK. Styran RM and Taylor RR (2016) This Colossal Project: Building the Welland Ship Canal, 1913-1932. McGill-Queen's University Press, Quebec and Ontario, Canada.

Sutherland RJM (ed.) (2016) Structural Iron 1750-1850 (Studies in the History of Civil Engineering), Routledge, Abingdon-on-Thames, UK. Taylor J (ed.) (2016) The Building Conservation Directory 2016: a Guide to Specialist Suppliers, Consultants and Craftspeople in Traditional
Building Conservation, Refurbishment and Design, 23rd edn. Cathedral Communications Ltd, Tisbury, UK.

Tomsin P (2015) Histoire des Techniques en Belgique: la Période Préindustrielle (Halleux R and Vandersmissen J (eds)). Les éditions de la Province de Liège, Liège, Belgium, vol. 1-3 (in French).

Van Balen K and Verstrynge E (eds) (2016) Structural Analysis of Historical Constructions: Anamnesis, Diagnosis, Therapy, Controls: Proceedings of the 10th International Conference Held in Leuven, Belgium on the 13-15 September 2016. CRC Press, Taylor \& Francis Group, Boca Raton, FL, USA.

Van de Voorde S, Bertels I and Wouters I (2015) Post-war Building Materials in Housing in Brussels 1945-1975. Vrij Universitiet, Brussels, Belgium

Wakelin P (2015) Pontcysyllte Aqueduct and Canal: World Heritage Site. CRT and RCAHMW, Milton Keynes and Aberystwyth, UK.

Waller D (2016) Iron Men: How One London Factory Powered the Industrial Revolution and Shaped the Modern World. Anthem Press, London, UK.

Ward L (2015) The London County Council bomb damage maps 1939 1945. Thames \& Hudson, London, UK. 